\title{
Thermal behavior, decomposition mechanism and some physicochemical properties of starch-g-poly(benzyl acrylate) copolymers
}

\author{
Marta Worzakowska ${ }^{1}$
}

Received: 27 February 2016/Accepted: 30 May 2016/Published online: 13 June 2016

(c) The Author(s) 2016. This article is published with open access at Springerlink.com

\begin{abstract}
TG/FTIR/QMS-coupled method to study the thermal behavior along with the evolution of volatile decomposition products and thus the decomposition mechanism under inert conditions of some starch-gpoly(benzyl acrylate) copolymers was applied. Starch-gpoly(benzyl acrylate) copolymers under $\mathrm{K}_{2} \mathrm{~S}_{2} \mathrm{O}_{8}$-initiated copolymerization process of benzyl acrylate monomer with gelatinized potato starch were prepared. The ATR-FTIR and ${ }^{13} \mathrm{C} C \mathrm{CP} / \mathrm{MAS}$ NMR confirmed the successful formation of grafted polymers with different grafting parameters such as grafting percent $(\% G)$ and grafting efficiency (\%GE). The evolution of some physicochemical properties such as swelling, moisture resistance and chemical resistance allowed certifying that the copolymers obtained were more resistant toward polar solvents, moisture and acidic medium due to the incorporation of more hydrophobic chains into starch backbone as compared to unmodified potato starch. The TG/FTIR/QMS studies confirmed their similar thermal stability, two stage decomposition process but different and more complex decomposition mechanism under the second decomposition stage as compared to the previously presented starch-g-poly(benzyl methacrylate) copolymers.
\end{abstract}

Keywords Potato starch - Benzyl acrylate - Graft copolymerization · TG/FTIR/QMS

Marta Worzakowska

marta.worzakowska@poczta.umcs.lublin.pl

1 Department of Polymer Chemistry, Faculty of Chemistry, Maria Curie-Skłodowska University, Gliniana 33 Street, 20-614 Lublin, Poland

\section{Introduction}

The physical and chemical modification of naturally occurring polymers are the promising methods in order to prepare more environmentally friendly, inexpensive, biodegradable materials with improved or new properties as compared to unmodified materials [1-6]. The chemical modification methods allow modifying both physical and chemical properties of natural polymers [7-9].

Among various chemical modification methods, grafting is the method which is intensively studied and applied for the modification of carbohydrate structure from many years. It resulted in the preparation of novel materials where to the main polymer carbohydrate chain, one or more side chains through covalent bonds are connected. Depending on the applications of the graft copolymers, varying degree of hydrophilic- and hydrophobic-type vinyl monomers can be incorporated into polysaccharide matrix [10-13]. Generally, the graft copolymerization process starts in the formation of active sites on the polysaccharide backbone which are the result of abstraction of a hydrogen atom from hydroxyl groups leading to the production the polymer radicals which then participate in the grafting of vinyl monomers. Various initiating systems in order to produce polymer radicals can be applied in the grafting process. Generally, radical initiators such as ceric salts, persulfates, redox systems or others are used. In addition, besides chemical methods of initiations, free radicals on the polysaccharide backbone can be formed with ultraviolet, electron beam irradiation or ${ }^{60} \mathrm{Co}$ [14-20]. Depending on the used initiating system, monomer type and its reactivity, polysaccharide type and other reaction conditions, the graft copolymers with different grafting parameters, various structure and thus various unique properties which can have a tremendous industrial potential as flocculants, 
supersorbents, sizing agents, thickeners and others can be prepared [21-26].

The present paper is the second part of our earlier studies [27]. The main objective of this paper was to study the thermal behavior, the type of volatile decomposition products, decomposition mechanism in inert atmosphere by applying TG/FTIR/QMS-coupled method of novel starchg-poly(benzyl acrylate) copolymers obtained under $\mathrm{K}_{2} \mathrm{~S}_{2} \mathrm{O}_{8}$-initiated grafting process of benzyl acrylate monomer onto gelatinized potato starch using the same synthesis conditions as previously applied, its structure by ATR-FTIR and ${ }^{13} \mathrm{C}$ CP/MAS NMR, evaluation of their some physicochemical properties and comparison of the results obtained to those presented in Ref. [27].

\section{Experimental}

\section{Materials}

The starch-g-poly(benzyl acrylate) copolymers under potassium persulfate (Merck, Germany)-initiated copolymerization process of gelatinized potato starch (Melvit S.A., Poland) and benzyl acrylate monomer (obtained according to Ref. [28]) in the presence of nitrogen as an inert atmosphere according to the procedure described elsewhere [27] have been obtained.

\section{Characterization of starch-g-poly(benzyl acrylate) copolymers}

The grafting parameters such as grafting percent $(\% G)$ and grafting efficiency (\%GE) were calculated using the equations given elsewhere [27, 29-31].

The ATR-FTIR spectra were carried out using a Fourier transform infrared (FTIR) spectrometer equipped with a diamond crystal (Tensor 27, Bruker, Germany). Each spectrum was gathered from 600 to $4000 \mathrm{~cm}^{-1}$ with a resolution of $4 \mathrm{~cm}^{-1}$.

${ }^{13} \mathrm{C}$ CP/MAS NMR were collected with applying Bruker Avance 300MSL apparatus (Germany). All the spectra were gathered at the frequency of $75.5 \mathrm{MHz}$.

The swellability coefficients $(B)$ of copolymers in polar (water, ethanol, butanol) and nonpolar (toluene, $\mathrm{CCl}_{4}$, hexane) solvents were determined by equilibrium swelling of the materials. $B$ values were evaluated based on Eq. 1:

$B=\frac{V_{\mathrm{s}}-V_{\mathrm{d}}}{V_{\mathrm{d}}} \times 100$

where $V_{\mathrm{s}}$ - the volume of the copolymer after swelling, $V_{\mathrm{d}}$ - the volume of the dry copolymer [27, 32, 33].

Percent moisture absorbance $(\% M)$ of copolymers was studied in an exsiccator where the $100 \mathrm{mg}$ of dried samples was exposure to the water vapor at $25{ }^{\circ} \mathrm{C}$ for $24 \mathrm{~h} . \% M$ was calculated from:

$\% M=\frac{m_{\mathrm{e}}-m_{\mathrm{i}}}{m_{\mathrm{i}}} \times 100$

where $m_{\mathrm{e}}$-the final mass of the sample, $m_{\mathrm{i}}$-the initial mass of the sample [27, 33, 34].

The ca. $100 \mathrm{mg}$ of the copolymers was treated with $1 \mathrm{M}$ $\mathrm{HCl}$ and $1 \mathrm{M} \mathrm{NaOH}$ until a constant mass of the sample was reached. After filtration, washing with distilled water and drying at $60{ }^{\circ} \mathrm{C}$, the residual was weighted and the chemical resistance toward basic and acidic media was calculated according to Eq. 3 .

$\% \mathrm{WL}=\frac{m_{1}-m_{2}}{m_{1}} \times 100$

where $m_{1}$-the initial mass of the sample, $m_{2}$-the final mass of the sample $[27,35]$. TG/FTIR/QMS-coupled method (STA 449 Jupiter F1, Netzsch coupled with TGA 585 Bruker spectrometer, Germany and QMS 403C Aëolos spectrometer, Germany) was applied in order to study the thermal properties of copolymers along with the evolution of volatile decomposition products and thus the decomposition mechanism of copolymers. In a typical procedure, ca. $10 \mathrm{mg}$ of the sample was heated from 40 up to $750{ }^{\circ} \mathrm{C}$ with a heating rate of $10{ }^{\circ} \mathrm{C} \mathrm{min}{ }^{-1}$ in open $\mathrm{Al}_{2} \mathrm{O}_{3}$ crucible under inert conditions (helium, flow rate $40 \mathrm{~mL} \mathrm{~min}^{-1}$ ). The FTIR spectra of volatile decomposition products emitted under heating the copolymers, from 600 to $4000 \mathrm{~cm}^{-1}$ wave number with a resolution of $4 \mathrm{~cm}^{-1}$ were gathered. The QMS spectra in the range from 10 to 150 amu were collected.

\section{Results and discussion}

\section{Characterization of starch-g-poly(benzyl acrylate) copolymers}

The grafting parameters of the copolymerization process of benzyl acrylate monomer onto gelatinized potato starch backbone in the presence of $\mathrm{K}_{2} \mathrm{~S}_{2} \mathrm{O}_{8}$ as an initiator in Table 1 are shown. According to the data presented, one can see that under changing the starch to monomer ratio from 1:0.25 to $1: 1.5$, the copolymers with different grafting percent $(\% G)$ can be prepared. As the starch to monomer ratio is increased from 1:0.25 up to $1: 1.25$, the grafting percent $(\% G)$ and grafting efficiency (\%GE) are increased and then decreased imperceptibly. The results are in accordance with other previous study $[27,33]$ and confirmed that in order to prepare the starch-g-poly(benzyl acrylate) copolymers with high grafting parameters, the starch to monomer ratio should be above $1: 1$. 
Table 1 Starch to monomer ratio and the grafting parameters

\begin{tabular}{llll}
\hline Sample & Starch to monomer ratio & GE/\% & G/\% \\
\hline Copolymer 1 & $1: 0.25$ & $55.6 \pm 0.4$ & $18.5 \pm 0.6$ \\
Copolymer 2 & $1: 0.5$ & $58.9 \pm 0.3$ & $24.8 \pm 0.5$ \\
Copolymer 3 & $1: 0.75$ & $63.2 \pm 0.5$ & $35.9 \pm 0.7$ \\
Copolymer 4 & $1: 1$ & $74.1 \pm 0.6$ & $41.5 \pm 0.4$ \\
Copolymer 5 & $1: 1.25$ & $77.8 \pm 0.4$ & $49.8 \pm 0.5$ \\
Copolymer 6 & $1: 1.5$ & $72.2 \pm 0.5$ & $45.2 \pm 0.6$ \\
\hline
\end{tabular}

Reaction parameters: temperature $-80{ }^{\circ} \mathrm{C}$, time $-2 \mathrm{~h}, 300 \mathrm{rmp}$, $\mathrm{K}_{2} \mathrm{~S}_{2} \mathrm{O}_{8}-1$ mass $\%$

The ATR-FTIR and ${ }^{13} \mathrm{C}$ CP/MAS NMR analyses were applied to confirm the grafting process of benzyl acrylate monomer onto starch backbone. The ATR-FTIR spectra of the example copolymer (copolymer 5) and non-modified potato starch are presented in Fig. 1. All the absorption signals responsible for the vibrations of atom groups which are present in the structure of non-modified potato starch $(-\mathrm{OH}, \mathrm{C}-\mathrm{H}, \mathrm{C}-\mathrm{O}$ stretching and $\mathrm{C}-\mathrm{H}$ deformation) are clearly observed from the ATR-FTIR spectra [27, 33, 36]. However, after chemical modification of potato starch, the appearance of new absorption bands: two bands at 3034 and at $3067 \mathrm{~cm}^{-1}\left(\mathrm{C}_{\mathrm{Ar}}-\mathrm{H}\right.$ stretching), at $1728 \quad(\mathrm{C}=\mathrm{O}$ stretching), two bands at 1452 and at $1496 \mathrm{~cm}^{-1}$ (aromatic $\mathrm{C}=\mathrm{C}$ stretching $)$ and two bands at 694 and $735 \mathrm{~cm}^{-1}\left(\mathrm{C}_{\mathrm{Ar}^{-}}\right.$ $\mathrm{H}$ out-of-plane deformation) [36] which directly confirmed the grafting of benzyl acrylate onto potato starch backbone is observed.

In addition, the structure of copolymers was identified based on ${ }^{13} \mathrm{C}$ CP/MAS NMR spectra (Fig. 2). The solidstate NMR spectrum shows the resonance signals for all carbon atoms present in the structure of starch, at 94.2-100.5 ppm (C1), at $81.5 \mathrm{ppm}(\mathrm{C} 4)$, at $72.3 \mathrm{ppm}(\mathrm{C}$

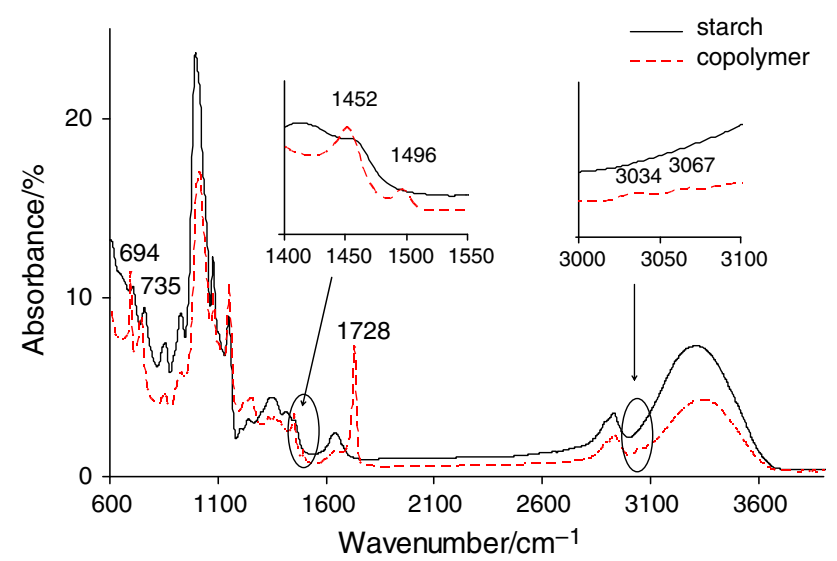

Fig. 1 ATR-FTIR spectra for potato starch and copolymer (copolymer 5)
2,3,5) and at $61.7 \mathrm{ppm}$ (C6) [37-39]. Meanwhile, on the solid-state NMR spectra for copolymers, new, additional resonance signals centered at $40.8 \mathrm{ppm}\left(\mathrm{C} \text { at }-\mathrm{CH}-\mathrm{CH}_{2}-\right)_{n}$ groups), at $128.5-136.4 \mathrm{ppm}$ (C in aromatic rings) and at $175.2 \mathrm{ppm}(\mathrm{C}$ in $\mathrm{C}=\mathrm{O})$ are appeared. When we are comparing, the ${ }^{13} \mathrm{C}$ CP/MAS NMR spectra before and after chemical modification of potato starch, it is worth noticing that the fall in the intensity of the $\mathrm{C} 2, \mathrm{C} 3$ and $\mathrm{C} 6$ carbon signals after grafting process is observed. It can be testified that both, primary and secondary hydroxyl groups of starch participate in the grafting process [37]. In addition, also, the changes in the intensity for $\mathrm{C} 4$ and $\mathrm{C} 1$ carbon signals for starch which may be due to the partial hydrolysis of glycosidic bonds under the preparation of copolymers were indicated [40].

\section{Properties of starch-g-poly(benzyl acrylate) copolymers}

The starch-g-poly(benzyl acrylate) copolymers are insoluble materials in available organic solvents. However, due to their variable hydrophilic-hydrophobic properties, the copolymers demonstrate various swelling in polar and nonpolar solvents, Fig. 3. According to Fig. 3, the copolymers are the materials which swelling is restricted in polar solvents such as water, ethanol and butanol as compared to non-modified potato starch. However, their swelling in nonpolar solvents (toluene, $\mathrm{CCl}_{4}$, hexane) is higher as compared to non-modified potato starch. Such behavior is connected with the modification of potato starch backbone by hydrophobic poly(benzyl acrylate) chains and is in accordance with our previous studies [27, 33]. In addition, due to the lower amount of hydroxyl groups in the structure of copolymers, the copolymers are more moisture restricted than potato starch. The percent moisture absorption changes from 40 up to $20 \%$ as the grafting percent is increased [27, 33] (Fig. 4).

The chemical resistance studies demonstrated that starch-g-poly(benzyl acrylate) copolymers were not resistant to basic environment. All the copolymers are fully gelated in $1 \mathrm{M} \mathrm{NaOH}$ medium. However, the copolymers prepared were more restricted to the acidic environment. The mass loss in $1 \mathrm{M} \mathrm{HCl}$ medium ranges from 31 to $34 \%$, and it was almost independent on the grafting percent (Table 2).

\section{Thermal properties of copolymers}

The characteristic TG/DTG curves of starch-g-poly(benzyl acrylate) copolymers are presented in Fig. 5. The $T_{\max }$, mass loss $(\Delta m)$ and residual mass at $740{ }^{\circ} \mathrm{C}(\mathrm{r} m)$ are collected in Table 3. Thermogravimetric analysis of copolymers revealed two major, non-well separated decomposition 
Fig. $2{ }^{13} \mathrm{C}$ CP/MAS NMR spectra for potato starch and copolymer (copolymer 5)

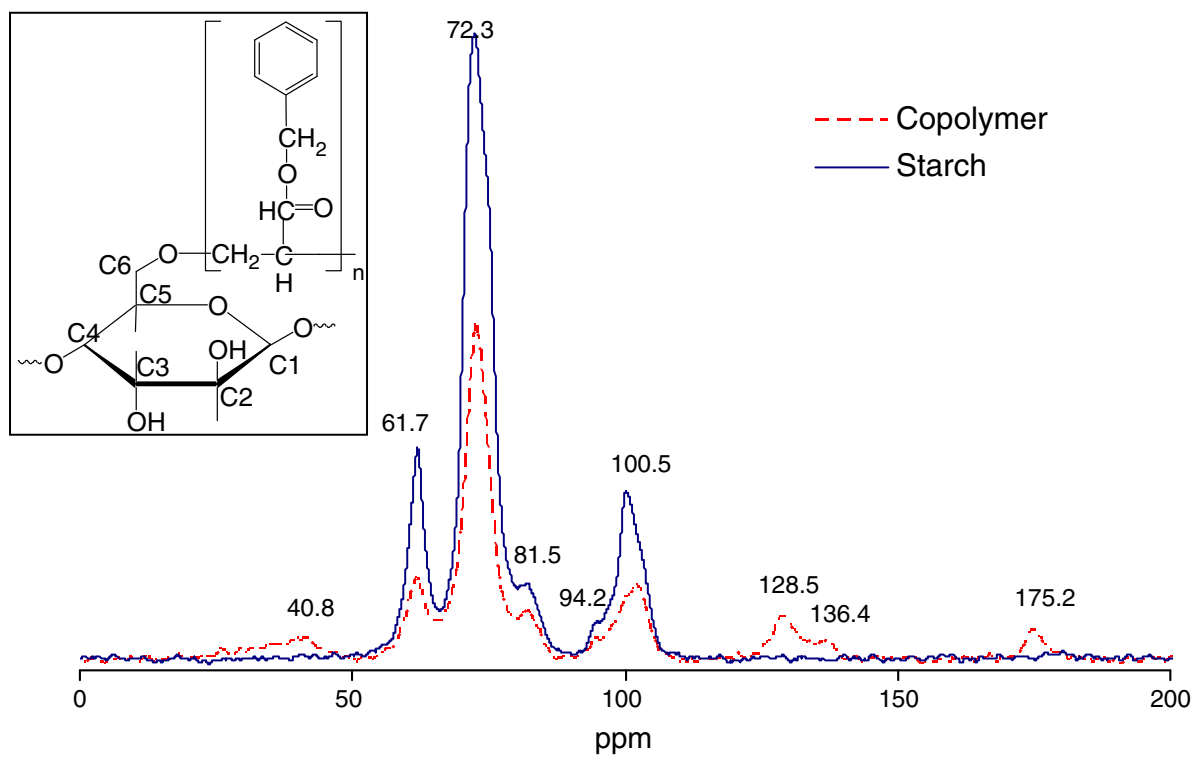

$\square$ Copolymer 1

$\square$ Copolymer 2

目 Copolymer 3

$\square$ Copolymer 4

SCopolymer 5

曰 $\mathrm{Copolymer} 6$

- Potato starch

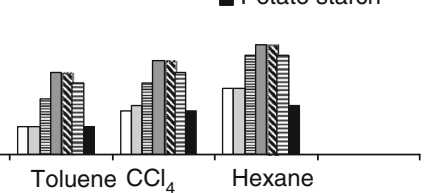

Fig. 3 Dependence of the swellability coefficients versus solvent type

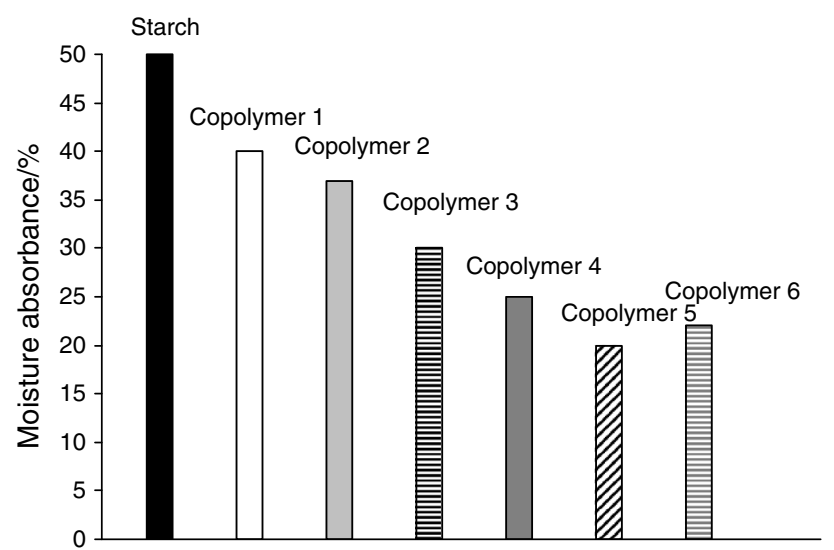

Fig. 4 Dependence of the percent moisture absorbance versus material type
Table 2 Chemical resistance of starch-g-poly(benzyl acrylate) copolymers

\begin{tabular}{lll}
\hline Sample & \multicolumn{2}{l}{$\% \mathrm{WL}$} \\
\cline { 2 - 3 } & $1 \mathrm{M} \mathrm{NaOH}$ & $1 \mathrm{M} \mathrm{HCl}$ \\
\hline Copolymer 1 & $\mathrm{g}$ & $33.6 \pm 0.3$ \\
Copolymer 2 & $\mathrm{g}$ & $32.8 \pm 0.4$ \\
Copolymer 3 & $\mathrm{g}$ & $31.5 \pm 0.5$ \\
Copolymer 4 & $\mathrm{g}$ & $31.0 \pm 0.5$ \\
Copolymer 5 & $\mathrm{g}$ & $31.0 \pm 0.4$ \\
Copolymer 6 & $\mathrm{g}$ & $34.0 \pm 0.6$ \\
\hline
\end{tabular}

g-completely gelatinized

stages between temperatures of ca. $200{ }^{\circ} \mathrm{C}$ up to ca. $560{ }^{\circ} \mathrm{C}$. Meanwhile, the mass loss of copolymers ranges from ca. $0.5 \%$ to ca. $1.7 \%$ at temperatures below $200{ }^{\circ} \mathrm{C}$ which was directly connected with the evaporation of moisture from copolymers under heating. However, the first decomposition stage of copolymers occurs at temperatures from ca. $200{ }^{\circ} \mathrm{C}$ to ca. $335{ }^{\circ} \mathrm{C}$ with $T_{\max 1} 288-292{ }^{\circ} \mathrm{C}$ and corresponds to a mass loss from 45.7 up to $33.7 \%$ of the mass initially present. The second decomposition stage between ca. 335 and $560{ }^{\circ} \mathrm{C}$ with $T_{\max 2} 388-395{ }^{\circ} \mathrm{C}$ and mass loss from 25.5 to $46.1 \%$ was happened. In addition, regarding to our previous study [27], the same relationship between grafting percent and mass loss under the first and second decomposition stages was indicated. Higher grafting percent was resulted in lower mass loss under the first decomposition stage but 

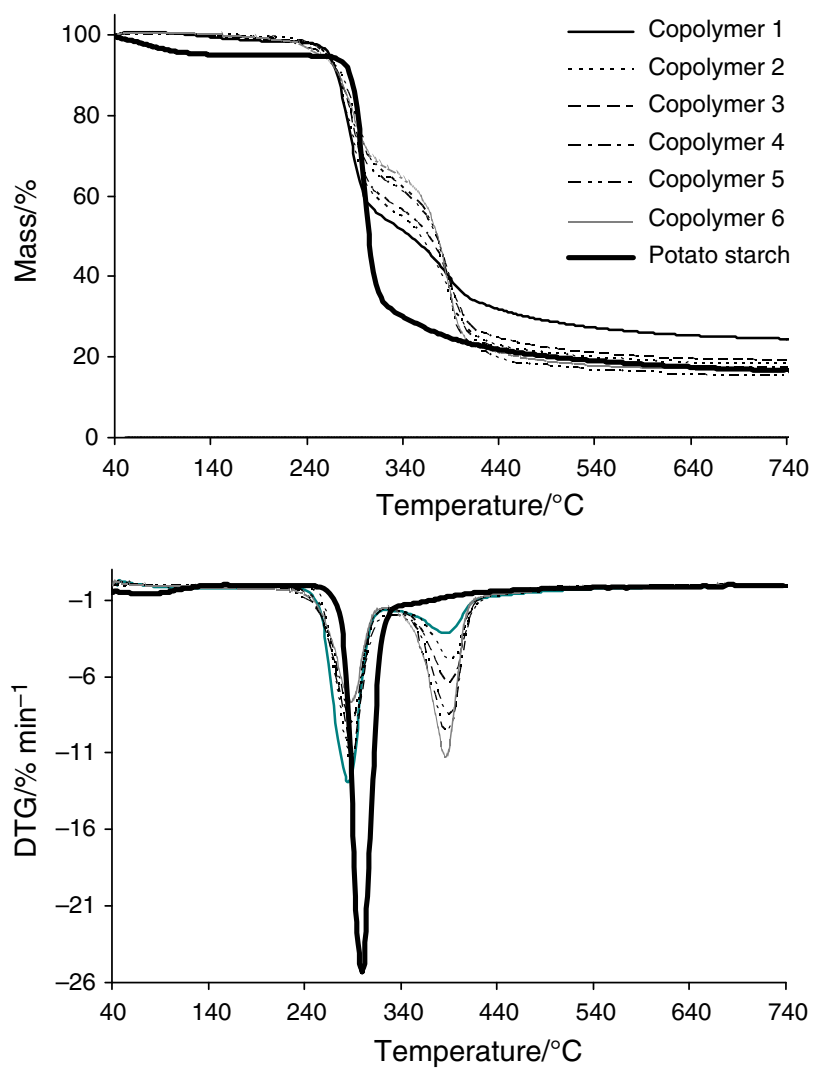

Fig. 5 TG/DTG curves

higher mass loss under the second decomposition stage. The heating of copolymers above temperature of $560{ }^{\circ} \mathrm{C}$ was resulted in further slow mass loss without the appearance of the DTG signal. The mass loss didn't exceed $2.5 \%$ in the temperature range of $560-740{ }^{\circ} \mathrm{C}$. The TG/DTG studies confirmed that the decomposition process of copolymers under inert conditions was not full. After heating of the materials up to $740{ }^{\circ} \mathrm{C}$, the residual mass corresponded to $25-15.5 \%$ of the initial sample mass was indicated.

\section{TG/FTIR/QMS studies}

TG/FTIR/QMS-coupled method was applied to describe and evaluate the degradation mechanism of starch-g- poly(benzyl acrylate) copolymers. The FTIR spectra of the volatile decomposition products emitted under decomposition of copolymers (from ca. 200 to $740{ }^{\circ} \mathrm{C}$ ) in inert conditions for copolymers with different grafting percent are presented in Fig. 6.

The FTIR spectra gathered at the temperature range 200-330 ${ }^{\circ} \mathrm{C}$ (first decomposition stage) are a typical spectra for the volatile decomposition products which are created under decomposition of starch from starch-gpoly(benzyl acrylate) copolymers which is in accordance with other studies [33, 41-43]. It confirmed that starch is a less thermally stable polymer as compared to benzyl acrylate chains grafted and decomposed mainly through the cleavage of glycosidic bonds, strong bonds and thermal dehydration processes forming as main gaseous decomposition products $\mathrm{CO}, \mathrm{CO}_{2}, \mathrm{H}_{2} \mathrm{O}$, aldehydes, alcohols, acids, aliphatics and furanes fragments [33, 41-43]. Thus, the thermal decomposition of starch from starch-gcopolymers results in the liberation of the polymer grafted from the copolymers which needs higher temperature in order to decompose. On the FTIR spectra collected at temperature range $330-460{ }^{\circ} \mathrm{C}$ (second decomposition stage), it is well visible the presence of the absorption bands characteristic for the stretching vibrations of $-\mathrm{OH}$ (3570-3730 $\mathrm{cm}^{-1}$ ), the stretching vibrations of $\mathrm{C}_{\mathrm{Ar}}-\mathrm{H}$ and $=\mathrm{C}-\mathrm{H}\left(3037-3070 \mathrm{~cm}^{-1}\right)$, the stretching vibrations of $\mathrm{C}-\mathrm{H}$ in $-\mathrm{CH}_{2}-$ (sym 2873 and asym $2931 \mathrm{~cm}^{-1}$ ), the stretching vibrations of $\mathrm{C}-\mathrm{H}$ in $\mathrm{O}=\mathrm{C}-\mathrm{H}\left(2720\right.$ and $\left.2780 \mathrm{~cm}^{-1}\right)$, the stretching vibrations of $\mathrm{C}=\mathrm{O}\left(1733 \mathrm{~cm}^{-1}\right.$ with a shoulder at $1780 \mathrm{~cm}^{-1}$ ), the stretching vibrations of aromatic $\mathrm{C}=\mathrm{C}$ (1492 and $1594 \mathrm{~cm}^{-1}$ ), the deformation vibrations of $\mathrm{C}-\mathrm{H}$ $\left(1378-1446 \mathrm{~cm}^{-1}\right)$, the stretching vibrations of $\mathrm{C}-\mathrm{O}$ $\left(1012-1280 \mathrm{~cm}^{-1}\right)$ and out-of-plane deformation vibrations of $=\mathrm{C}-\mathrm{H}$ and $\mathrm{C}_{\mathrm{Ar}-\mathrm{H}}\left(694-902 \mathrm{~cm}^{-1}\right)$. Besides those above bands, the bands responsible for the vibrations of $\mathrm{CO}$ (2000-2200 $\left.\mathrm{cm}^{-1}\right), \mathrm{CO}_{2}\left(670\right.$ and $\left.2330-2365 \mathrm{~cm}^{-1}\right)$ and $\mathrm{H}_{2} \mathrm{O}$ (above $3500 \mathrm{~cm}^{-1}$ ) [42, 43] are well documented on the FTIR spectra. Regarding the occurrence of the characteristic absorption signals on the FTIR spectra under the second decomposition stage and the structure of poly(benzyl acrylate), it can be suspected that the main decomposition processes are the result of the both random

Table 3 TG/DTG data for starch-g-poly(benzyl acrylate) copolymers

\begin{tabular}{lllllllll}
\hline material & $T_{\max 0} /{ }^{\circ} \mathrm{C}$ & $\Delta m_{0} / \%$ & $T_{\max 1} /{ }^{\circ} \mathrm{C}$ & $\Delta m_{1} / \%$ & $T_{\max 2} /{ }^{\circ} \mathrm{C}$ & $\Delta m_{2} / \%$ & $\Delta m_{3} / \%$ & $\mathrm{r} m / \%$ \\
\hline Copolymer 1 & 130 & 1.7 & 288 & 45.7 & 390 & 25.5 & 2.1 & 25.0 \\
Copolymer 2 & 133 & 1.7 & 288 & 43.2 & 395 & 35.5 & 1.1 \\
Copolymer 3 & 117 & 1.2 & 290 & 41.7 & 392 & 36.6 & 1.5 \\
Copolymer 4 & 118 & 1.2 & 288 & 36.8 & 391 & 43.6 & 1.1 \\
Copolymer 5 & 115 & 0.6 & 292 & 36.5 & 390 & 46.1 & 1.3 \\
Copolymer 6 & 112 & 0.5 & 290 & 33.7 & 388 & 45.0 & 1.0 \\
\hline
\end{tabular}


Fig. 6 FTIR spectra for copolymer 1 , copolymer 3 , copolymer 4 and copolymer 6
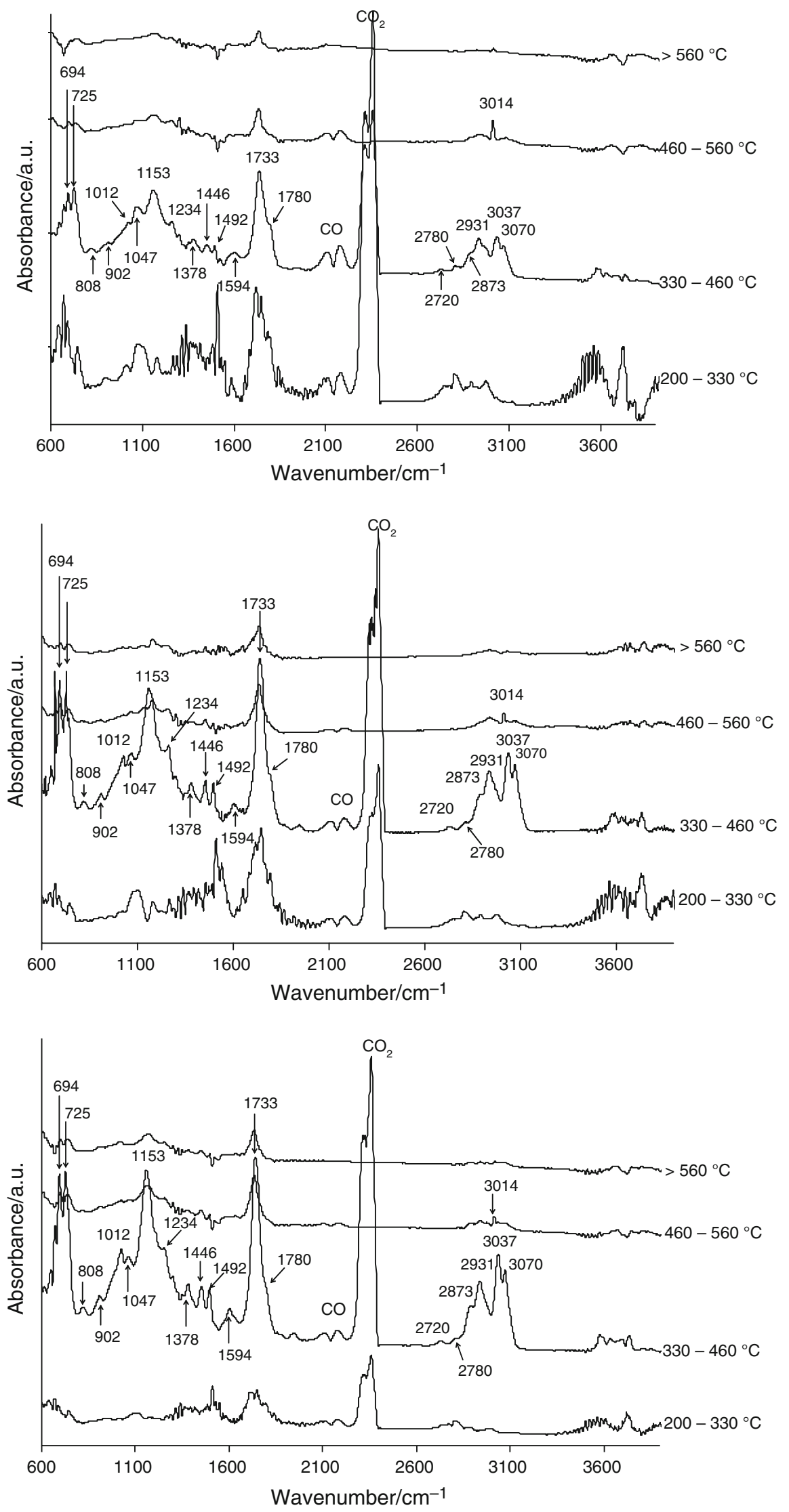
Fig. 6 continued
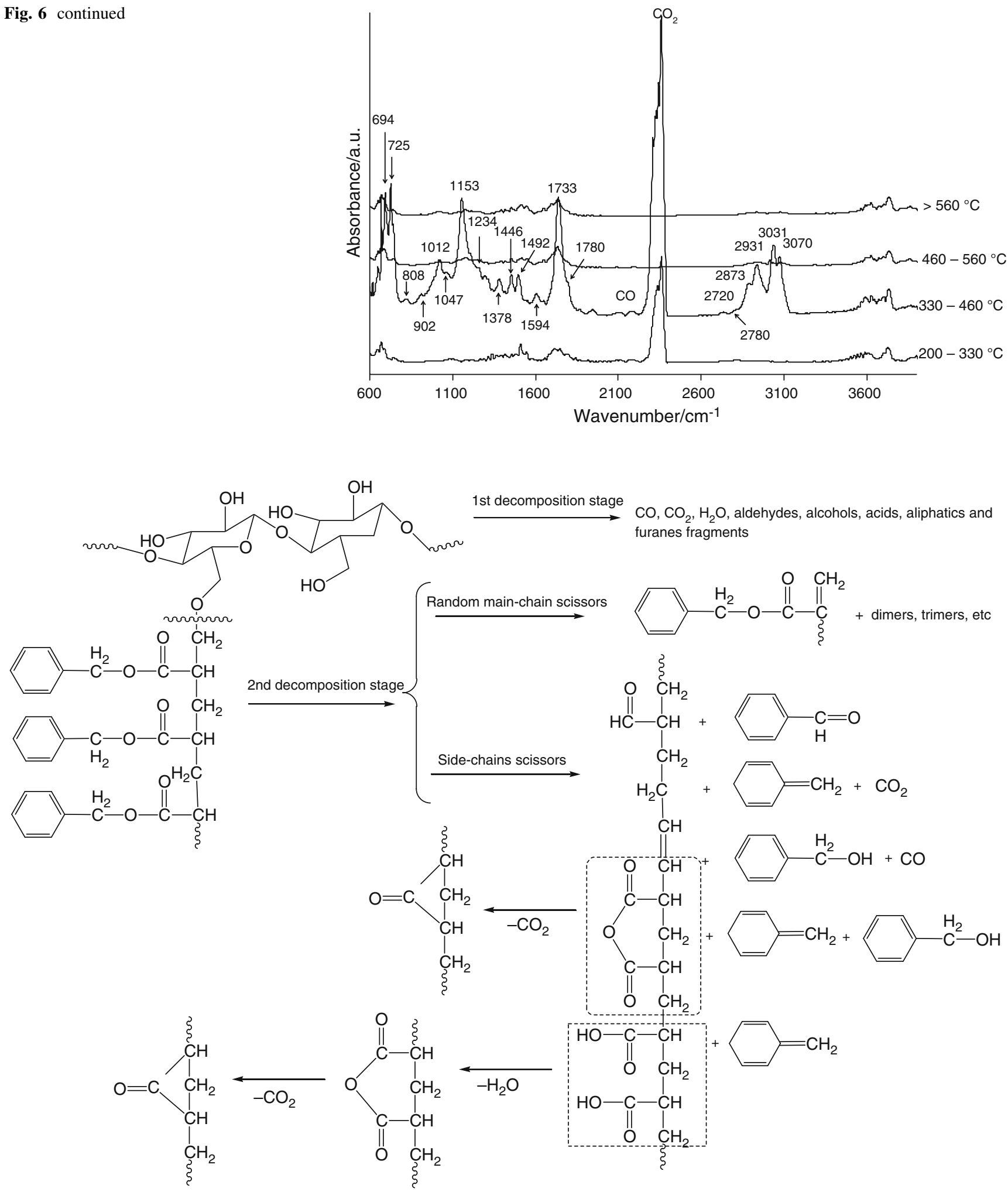

Scheme 1 Mode of the decomposition path of starch-g-poly(benzyl acrylate) copolymers

main-chain scissors and side-chain scissors [44, 45], as it is presented in Scheme 1. As a result the mixture of organic and inorganic volatile decomposition products is emitted under the second decomposition stage. Among them, the most feasible organic volatile decomposition products are alkene, aromatic, alcohol, aldehyde, acid or cyclic ketone 

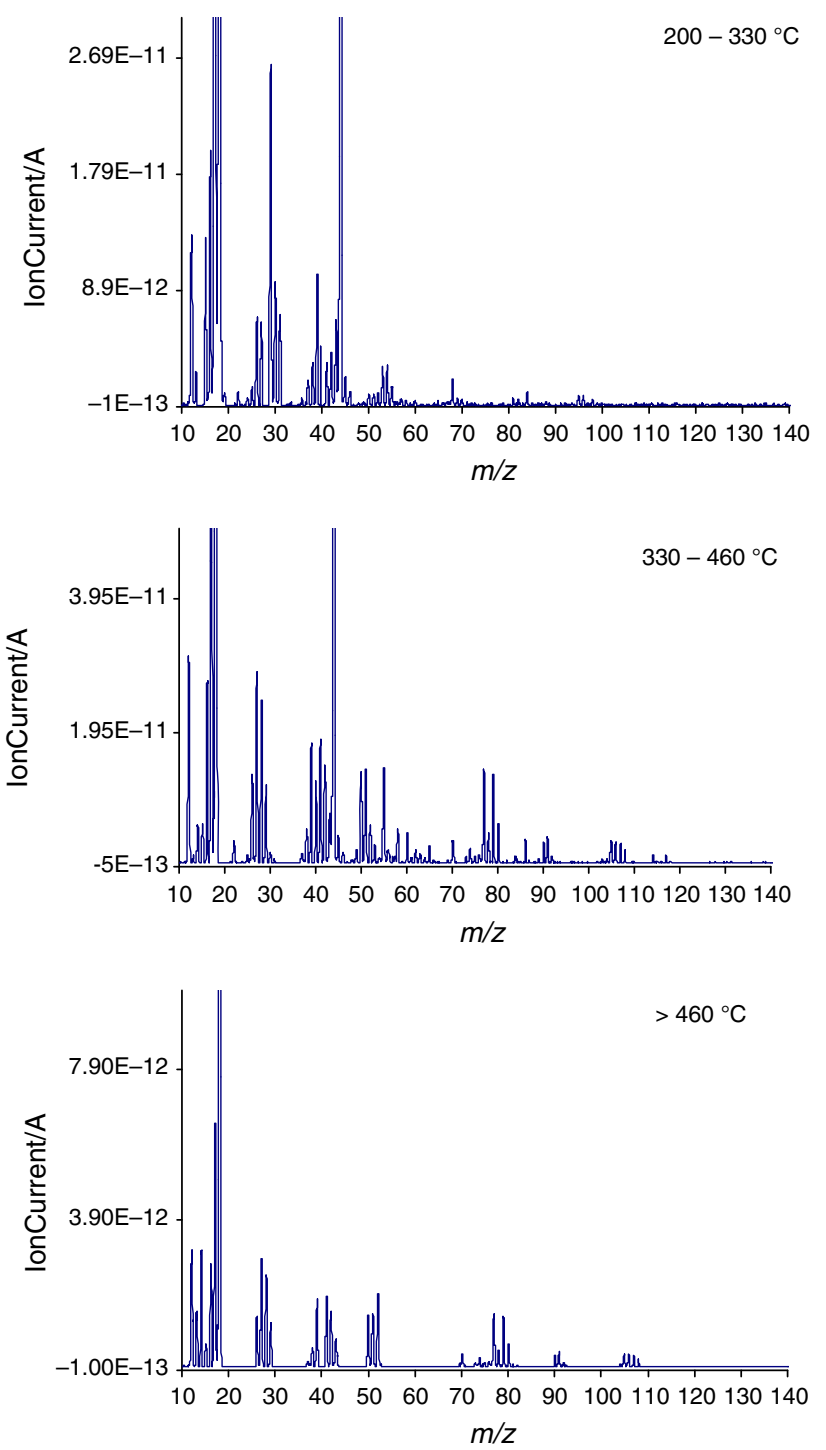

Fig. 7 QMS spectra of volatile decomposition products emitted under heating of copolymer 3

fragments and benzyl acrylate monomer as it is shown in Scheme 1.

The further heating of the residue formed above $460{ }^{\circ} \mathrm{C}$ resulted in the emission of $\mathrm{CH}_{4}\left(3014 \mathrm{~cm}^{-1}\right), \mathrm{CO}$ (2000-2200 $\mathrm{cm}^{-1}$ ), $\mathrm{H}_{2} \mathrm{O}$ (above $3500 \mathrm{~cm}^{-1}$ ) [42, 43, 46-49] and some of the other less volatile organic fragments. According to the FTIR spectra gathered at temperatures higher than $460{ }^{\circ} \mathrm{C}$, the appearance of the small intensity signals responsible for the stretching vibrations of $\mathrm{C}_{\mathrm{Ar}-\mathrm{H}}$ and $=\mathrm{C}-\mathrm{H}\left(3037-3070 \mathrm{~cm}^{-1}\right)$, the stretching vibrations of $\mathrm{C}-\mathrm{H}$ (2873-2931 $\left.\mathrm{cm}^{-1}\right)$, the stretching vibrations of $\mathrm{C}=\mathrm{O}$ $\left(1733 \mathrm{~cm}^{-1}\right)$, the deformation vibrations of $\mathrm{C}-\mathrm{H}$ $\left(1378-1446 \mathrm{~cm}^{-1}\right)$, the stretching vibrations of $\mathrm{C}-\mathrm{O}$ $\left(1012-1280 \mathrm{~cm}^{-1}\right)$ and out-of-plane deformation vibrations of $=\mathrm{C}-\mathrm{H}$ and $\mathrm{C}_{\mathrm{Ar}-\mathrm{H}}\left(694-902 \mathrm{~cm}^{-1}\right)$ which can be due to the emission of mainly alkene, aromatic, alcohol or ketone fragments is observed. The type of the decomposition products emitted at higher temperatures may indicate on the further secondary reactions between the decomposition products and/ or residue formed [27].

Additionally performed QMS analysis directly confirmed the FTIR results. Due to the same volatile decomposition products emitted under heating of all copolymers studied, the exemplary QMS spectra gathered at the first decomposition stage $\left(200-330{ }^{\circ} \mathrm{C}\right)$, at the second decomposition stage $\left(330-460{ }^{\circ} \mathrm{C}\right)$ and above $460{ }^{\circ} \mathrm{C}$ are presented in Fig. 7. The appearance of $m / z$ ions typical for the gaseous products evolved under decomposition of potato starch from the copolymers studied under the first decomposition stage was indicated. One can clearly see the presence of $\mathrm{m} / z$ ions characteristic for $\mathrm{CO}_{2}$ (44), $\mathrm{CO}$ (28), $\mathrm{H}_{2} \mathrm{O}(18,17,16)$ and organic fragments: furanes $(50,51,52$, $53,68,69,82,95,96)$, aldehydes $(15,26,28,29,30,41$, $42,43)$, alcohols $(31,45,29,27,46,43,26,30)$, acids (13, $28,29,30,41,42,43,45,46)$ and aliphatics $(30,29,28,27$, 26) [50]. However, on the QMS spectra for copolymers gathered at the second decomposition stage, the formation of organic fragments such as benzaldehyde $(\mathrm{m} / \mathrm{z}: 77,106$, $105,51,50,78,52,74,107,39)$, benzyl alcohol $(\mathrm{m} / \mathrm{z}: 79$, $108,107,77,51,91,78,50,39,80)$, cyclobutanone $(\mathrm{m} / \mathrm{z}$ : $42,70,41,39,27,26,43,14,38,28)$, glutaric anhydride $(\mathrm{m} / \mathrm{z}: 42,70,44,41,27,39,26,43,40,29)$, glutaric acid $(\mathrm{m} / \mathrm{z}: 86,42,45,55,60,41,58,39,43,114)$, dienes $(\mathrm{m} / \mathrm{z}$ : $79,80,77,39,51,78,50,52,27,38)$, benzyl acrylate $(\mathrm{m} / \mathrm{z}$ : $91,55,117,90,107,79,77,65)$ and inorganic species $\left(\mathrm{CO}_{2}, \mathrm{CO}, \mathrm{H}_{2} \mathrm{O}\right)$ indicated mainly on the decomposition process of poly(benzyl acrylate) from the copolymers. The heating of copolymers above the temperature of $460{ }^{\circ} \mathrm{C}$ resulted in the emission of $\mathrm{CH}_{4}(16,15,14,13), \mathrm{CO}(28)$, $\mathrm{H}_{2} \mathrm{O}(16,17,18)$ and some amount of organic products, among them the most feasible were aromatic fragments: $(\mathrm{m} / \mathrm{z}: 77,79,106,105,51,50,78,80,91,108,52,74,107$, $39)$, dienes $(\mathrm{m} / \mathrm{z}: 79,80,77,39,51,78,50,52,27,38)$ and ketones $(\mathrm{m} / \mathrm{z}: 42,70,41,39,27,26,43,14,38,28)$ [50].

The TG/FTIR/QMS data confirmed that the decomposition mechanism of starch-g-poly(benzyl acrylate) copolymers was completely different and more complex as compared to the decomposition mechanism of the previously studied starch-g-poly(benzyl methacrylate) copolymers [27].

\section{Conclusions}

The ATR-FTIR and ${ }^{13} \mathrm{C}$ CP/MAS NMR analyses confirmed the successful preparation of starch-g-poly(benzyl acrylate) copolymers under the grafting process of benzyl acrylate monomer onto gelatinized potato starch backbone in the presence of $\mathrm{K}_{2} \mathrm{~S}_{2} \mathrm{O}_{8}$ as an initiator. The copolymers 
obtained were characterized by lower swelling in polar than in nonpolar solvents and higher moisture resistant than non-modified potato starch. Their swelling and moisture resistance were directly depended on the grafting percent which was in accordance with our previous results. However, the chemical resistance of starch-g-poly(benzyl acrylate) copolymers was completely different as compared to previously described starch-g-poly(benzyl methacrylate) copolymers. The starch-g-poly(benzyl acrylate) copolymers were gelatinized completely when treated with basic medium. In addition, their resistance toward acidic medium was almost independent on the grafting percent. The thermal stability and the decomposition course of starch-g-poly(benzyl acrylate) and starch-gpoly(benzyl methacrylate) copolymers were similar. The first decomposition stage of copolymers was connected with the cleavage of glycosidic bonds, strong bonds and thermal dehydration processes of starch from copolymers which resulted in the emission of the typical for starch gaseous decomposition products such as $\mathrm{CO}, \mathrm{CO}_{2}, \mathrm{H}_{2} \mathrm{O}$, aldehydes, alcohols, acids, aliphatics and furanes fragments. Meanwhile, the second degradation stage of copolymers was run through completely different and more complex mechanism as compared to starch-g-poly(benzyl methacrylate) copolymers as it was confirmed by applying the TG/FTIR/QMS-coupled method. Under this decomposition stage, random main-chain scissors and side-chain scissors were happened which caused the formation of the mixture of inorganic and organic species such as $\mathrm{CO}, \mathrm{CO}_{2}$, $\mathrm{H}_{2} \mathrm{O}$, alkene, aromatic, alcohol, aldehyde, acid or cyclic ketone fragments and benzyl acrylate monomer.

Open Access This article is distributed under the terms of the Creative Commons Attribution 4.0 International License (http://crea tivecommons.org/licenses/by/4.0/), which permits unrestricted use, distribution, and reproduction in any medium, provided you give appropriate credit to the original author(s) and the source, provide a link to the Creative Commons license, and indicate if changes were made.

\section{References}

1. Cumpstey I. Chemical modification of polysaccharides. ISRN Organic Chemistry. Cario: Hindawi Publishing Corporation; 2013.

2. Carraher ChE Jr, Gehrke TJ. Chemical modification of polysaccharides-modification of dextran through interfacial condensation with organostannane halides. In: Carraher ChE Jr, Moore JA, editors. Modification of polymers. New York: Plenium Press; 1983.

3. Dodi G, Hritcu D, Popa MI. Carboxymethylation of guar gum: synthesis and characterization. Cellul Chem Technol. 2011;45:171-6.

4. Desbrières J, Petit Ch, Reynaud S. Microwave-assisted modifications of polysaccharides. Pure Appl Chem. 2014;86:1695-706.

5. Yalpani M. Polysaccharides-syntheses, modifications and structure/property relations. Amsterdam: Elsevier; 1988.
6. Zhang N, Chen H, Ma L, Zhang Y. Physical modifications of polysaccharide from Inonotus obliquus and the antioxidant properties. Int J Biol Macromol. 2013;54:209-15.

7. Xie W, Xu P, Liu Q, Xue J. Graft-copolymerization of methylacrylic acid onto hydroxypropyl chitosan. Polymer Bull. 2002;49:47-54.

8. IIlter S, Hazer B, Borcakli M, Atici O. Graft copolymerization of methyl methacrylate onto bacterial polyester containing unsaturated side chains. Macromol Chem Phys. 2001;202:2281-6.

9. Cacmakli B, Hazer B, Borcakli M. Polystyreneperoxide and poly(methyl methacrylate) peroxide for grafting on unsaturated bacterial polyesters. Macromol Biosci. 2001;1:348-54.

10. Brandrup J. Polymerization and depolymerization. In: Brandrup J, Immergut EH, editors. Polymer handbook. 3rd ed. New York: Wiley; 1989. p. 1-36.

11. Gupta KC, Sahoo S. Grafting of acrylaonitrile and methyl methacrylate from their binary mixtures on cellulose using ceric ions. J Appl Polym Sci. 2001;79:767-78.

12. Song H, Zhang SF, Ma XC, Wang DZ, Yang J. Synthesis and application of starch-graft-poly(AM-co-AMPS) by using a complex initiation system of CS-APS. Carbohydr Polym. 2007;69:189-95.

13. Jett C, Arthur J. Grafting studies on cotton cellulose. J Macromol Sci Part A. 1976;10:653-70.

14. Mino G, Kaizerman S. A new method for the preparation of graft copolymers. Polymerization initiated by ceric ion redox systems. J Polym Sci. 1958;31:242-3.

15. Vazquez B, Goni I, Gurruchaga M, Areizaga J, Valero M, Guzman GM. Ceric ion consumption in graft copolymerization of methacrylonitrile/methacrylate mixtures onto amylomaize. Makromol Chem. 1992;193:2189-98.

16. Hebeish A, Bayazeed A, El-Alfy E, Khalil MI. Synthesis and properties of polyacrylamide-starch graft copolymers. Starch/ Stärke. 1988;40:223-9.

17. Fanta GF, Swanson CL, Burr RC, Doane WM. Polysaccharide-gpolystyrene copolymers by persulfate initiation: Preparation and properties. J Appl Polym Sci. 1983;28(7):2455-61.

18. Brockway CE, Moser KB. Grafting of poly(methyl methacrylate) to granular corn starch. J Polym Sci Part A. 1963;1:1025-39.

19. Mehrotra R, Ranby B. Graft copolymerization onto starch. I. Complexes of $\mathrm{Mn} 3+$ as initiators. J Appl Polym Sci. 1987;21:1647-54.

20. Fanta GF, Doane WM. Grafted starches, properties and uses. In: Wurzburg OB, editor. Modified starches: properties and uses. Boca Raton: CRC Press; 1987. p. 149.

21. Cao J, Luo YCh, Xu GQ, Qi L, Hu XQ, Xu PF, Zhang LY, Cheng SY. Utilization of starch graft copolymers as selective depressants for lizardite in the flotation of pentlandite. Appl Surf Sci. 2015;337:58-64.

22. Jyothi AN. Starch graft copolymers: novel applications in industry. Compos Interfaces. 2010;17:165-74.

23. Witono JR, Noordergraaf IW, Heeres HJ, Janssen LPBM. Graft copolymerization of acrylic acid to cassava starch-evaluation of the influences of process parameters by an experimental design method. Carbohyd Polym. 2012;90:1522-9.

24. Shogren RL, Willett JL, Biswas A. HRP-mediated synthesis of starch-polyacrylamide graft copolymers. Carbohyd Polym. 2009;75:189-91.

25. Wang L, Shen J, Men Y, Wu Y, Peng Q, Wang X, Yang R, Mahmood K, Liu Z. Corn starch-based graft copolymers prepared via ATRP at the molecular level. Polym Chem. 2015;6:3480-8.

26. Sadeghi M, Heidari B. Crosslinked graft copolymer of methacrylic acid and gelatin as a novel hydrogel with $\mathrm{pH}$-responsiveness properties. Materials. 2011;4:543-52.

27. Worzakowska M. Starch-g-poly(benzyl methacrylate) copolymers Characterization and thermal properties. J Therm Anal Calorim. 2016;. doi:10.1007/s10973-016-5328-7. 
28. Grochowicz M, Gawdzik B. Preparation and characterization of porous crosslinked microspheres of new aromatic methacrylates. J Porous Mater. 2013;20:339-49.

29. Athawale VD, Rathi SC. Role and relevance of polarity and solubility of vinyl monomers in graft polymerization onto starch. React Funct Polym. 1997;34:11-7.

30. Fakhru'l-Razi A, Qudsieh IYM, Yunus WMZW, Ahmad MB, Rahman MZA. Graft copolymerization of methyl methacrylate onto sago starch using ceric ammonium nitrate and potassium persulfate as redox initiator system. J Appl Polym Sci. 2001;82:1375-81.

31. Fares MM, El-Faqeeh AAS, Osman MN. Graft copolymerization onto starch-I. Synthesis and optimalization of starch grafted with $N$-tert-bytylacrylamide copolymer and its hydrogels. J Polym Res. 2003;10:119-25.

32. Tuncel K, Ecevit K, Kesenci K, Piskin E. Nonswellable and swellable ethylene glycol dimethacrylate-acrylic acid copolymer microspheres. J Polym Sci Part A Polym Chem. 1996;34:45-55.

33. Worzakowska M, Grochowicz M. Effect of some parameters on the synthesis and the physico-chemical properties of new amphiphilic starch-g-copolymers. Carbohydr Polym. 2015; 130:344-52.

34. Pathania D, Sharma R. Synthesis and characterization of graft copolymers of metyhacrylic acid onto gelatinized potato starch using chromic acid initiator in presence of air. Adv Mater Lett. 2012;3:136-42.

35. Kaith BS, Singha AS, Grupa SK. Graft copolymerization of flax fibres with binary vinyl monomers mixtures and evaluation of swelling, moisture absorption and thermal (behavior of the grafted fibres. J Polym Mater. 2003;20:195-9.

36. Sokrates G. Infrared and Raman characteristic group frequences, tables and charts. New York: Wiley; 2001.

37. Nasim T, Patra A, Gosh S, Panda AB. Microwave assisted synthesis of polyacrylamide grafted dextrin (Dxt-g-PAM): development and application of a novel polymeric flocculant. Int J Biol Macromol. 2010;47:623-31.

38. Salimi K, Yilmaz M, Rzayev ZMO, Piskin E. Controlled graft copolymerization of lactic acid onto starch in a supercritical carbon dioxide medium. Carbohydr Polym. 2014;114:149-56.
39. Wang S, Wang Q, Fan X, Xu J, Zhang Y, Yuan Y, Jin H, CavacoPaulo A. Synthesis and characterization of starch-poly(methyl acrylate) graft copolymers using horseradish peroxidase. Carbohydr Polym. 2016;136:1010-6.

40. Karst DT, Yang Y, Tanaka G. An explanation of increased hydrolysis of the b-(1,4)-glycosidic linkages of grafted cellulose using molecular modeling. Polymer. 2006;47:6464-71.

41. Liu Z, Li W, Zhang Y, Wang J, Orndorff W, Pan WP. Influence of biomass on coal combustion based on thermogravimetry and Fourier transform infrared spectroscopy. J Therm Anal Calorim. 2015;122:1289-98.

42. NIST Chemistry Webbook. NIST Standard Reference Data 2011: http://webbook.nist.gov.

43. Liu X, Yu L, Xie F, Li M, Chen L, Li X. Kinetics and mechanism of thermal decomposition of cornstarches with different amylose/ amylopectin ratios. Starch/Stärke. 2010;62:139-46.

44. Cameron GG, Kane DR. The thermal degradation of poly(benzyl acrylate). Polymer. 1968;9:461-70.

45. Cameron GG, Kane DR. The thermal degradation of poly(methyl acrylate). III. The mechanism of volatile formation. Macromol Chem Phys. 1968;113:75-84.

46. Huo JX, Wang Y, Zhang DH, Ren N, Zhang JJ. Syntheses, characterization, luminescence, and thermal decomposition mechanism of four lanthanide complexes with 4-ethylbenzoic acid and terpyridine. J Therm Anal Calorim. 2016;. doi:10.1007/ s10973-016-5266-4.

47. Silva ACM, Gálico DA, Guerra RB, Perpétuo GL, Legendre AO, Rinaldo D, Bannach G. Thermal stability and thermal decomposition of the antihypertensive drug amlodipine besylate. J Therm Anal Calorim. 2015;120:889-92.

48. Cássia da Silva R, Cavalheiro ETG. Synthesis, characterization, and thermal analysis of alginate and monoethanolamine product. J Therm Anal Calorim. 2015;120:855-62.

49. Yang J, Chen H, Zhao W, Zhou J. Combustion kinetics and emission characteristics of peat by using TG-FTIR technique. J Therm Anal Calorim. 2015; doi:10.1007/s10973-015-5168-x.

50. NIST chemistry webbook standard reference database number 69 , 2011: http://webbook.nist.gov/chemistry. 